\title{
Introduction
}

\section{C.W.R.D. Moseley}

Dryden, in that famous Preface to the Fables (1700), remarked, '...there is such a variety of game springing up before me, that I am distracted in my choice, and know not what to follow. It is sufficient to say, according to the proverb, that here is God's plenty'. That remark, especially the last phrase, has stuck to the Chaucer he re-presented, and with justice. This editor could in all humility echo Dryden: the range of topics to discuss, which deep reading in and around Chaucer suggests, is vast, and the range of interest in the articles in these two special issues of Critical Survey on Chaucer runs down only some of the game.

Why do we still read and argue about Chaucer? After all, the crass neophilia that rules so much of our culture would readily dismiss the work of someone dead for over six hundred years as of no importance to us. He did indeed live in a world immeasurably and unknowably different in assumptions and behaviour from ours. The simplest answers to my question may be the best: he is fun - very important, for rational pleasure is one of the proper pursuits of mankind - and he challenges our intelligence and questions our certainties. Great writing - indeed, great art of any kind - transcends the conventions and contexts of its time, and Chaucer has outlasted many -isms. He is by any standards a coruscating intellect, and also a meticulous craftsman, as Ad Putter's article demonstrates. But his poetry can also be immensely moving in that inexplicable way that defeats all analysis. He gives us a line, if we will listen to him, on this puzzle of being human, and despite the nearly seven centuries between the light he saw and ours, he articulates the human imperatives. Dryden again: '... for mankind is ever the same, and nothing is lost out of nature, though everything is altered'. Even so, making poetry out of normality is an art that requires the agile processing skills of a poet as well as those of his readers, and those are worth exploring. 
But tot homines, quot sententiae: like the birds in The Parlement of Foulys, critics and readers of Chaucer over the long centuries have argued many things about his work, often wholly consistently in themselves, but frequently incompatibly. 'In forme of speche is chaunge'.... Times change. The vagaries of critical fashion, New or not, have taken us on tours of various Fallacies, Intentional, Authorial and even perhaps Narratorial; they have taken us through long arguments proving that arguments prove nothing and that all we have is a play of signifiers. And the whirligig of Time seems for some now to have brought us to the Resurrection of the Author ${ }^{1}$ - though not without a wholly welcome understanding that the different stances and capacities of readers affect the poem that they see. In the welter of critical cleverness, it is so easy quietly to forget that writers, real people, existed and wrestled with the intractability of language: when all is said and done, we are dealing with a unique vision of one person in one temporal context. Writers developed different ideas and perspectives as they grew older; they read books and sometimes they misunderstood them - or saw what they wanted to see. And they said what they wanted to say in that serious game with an audience or reader - whose taste they understood and with whom they could leave a lot unsaid. They were not simply contextless events, however finally unattainable to us is the mentalité they took for granted. (That is certainly not to say the attempt is not worth making.) But when they are tellers of stories, they raise another problem. Just as with Shakespeare, we cannot really know for certain what Chaucer thought, only about what was 'thought' by his personae and his characters - if that word is appropriate without qualification. And while Chaucer's characters might 'read' books, and even like the Black Knight 'write' poems or, as in Canterbury Tales [CT], narrate stories, that narration, that 'reading', is itself narrated.

Chaucer speaks to us in our confused and conflicted post-modern world with a peculiar sharpness. This might be one reason why it is high folly not to teach him to the young, and why, when you do, they respond so enthusiastically. The Middle Ages had much more in common with modernism, indeed with our own uncertainties, than with the confidence of the nineteenth century when so much spadework was done in recovering and re-examining many of the materials we value. The medievals shared our itchy unease about what constitutes truth in statement, or the reliability of knowledge; the non-naturalistic representation of time in the polychronicity of some 
visual art; the sophistication of entrelace, which makes the narration of Scandi-noir TV series like The Bridge seem like child's play. In the Luttrell Psalter, horses climb, apparently cheerfully to judge from their expression, out of one plane into the side margin. As Helen Cooper has remarked in a private note to me, the medievals 'delighted in Picassoesque clashes of perspective', and in playing with what Jonathan Bate has called 'aspectuality', where contradictory things can both be true which Hopkins also knew:

This Jack, joke, poor potsherd, patch, patch, matchwood, immortal diamond, Is immortal diamond. ${ }^{2}$

Chaucer delights in de-authorizing the act of authorship, as in Troilus and Criseyde, or in presenting us with unreliable personae as guides to his problematic fictional worlds. He has no trouble in Sternely moving between different storytelling/narratorial levels, or different implied audiences, even within the same tale. ${ }^{3}$ Just so the Man of Law can be sniffy about the poems by his own author he has 'read' - but that author is also a fictional character in the same narrative space/time as himself (CT II.46ff.); just so Justinus cites the Wife of Bath, or the fictional Parson condemns fiction: 'Thou getest fable noon ytold for me...' (CT X.31ff.).

Chaucer's poems remain, challenging the effectiveness of whatever tools we bring to them, and ultimately, like all great art, they remain inexhaustible and beyond the categorizing reach of changing fashion or taste. The poems read us, one might say, as well as the other way round. All we can do is hope one day 'to fare / The bet, and thus to rede [we] nyl nat spare'.

The whole point about stories is that they say what cannot be said. Humans are not the only intelligent creatures on this planet, but as far as we know, we are the only species that makes sense of the world by telling each other stories about it: homo sapiens sapiens, but also homo sapiens narrans. A pupil of mine, a mature student who had been a ballet dancer, when once asked what her dance had meant, replied, 'If I could say what my dance meant, I would not need to dance it'. Exactly. What does Troilus and Criseyde 'mean'? Or King Lear? To Conrad's Marlow, 'the meaning of an episode was not inside like a kernel but outside enveloping the tale which brought it out only as a glow brings out a haze, in the likeness of one of those misty haloes that sometimes are made visible by the spectral illumination of moonshine'. ${ }^{4}$ The 
experience is the meaning. To understand - but we never shall - that experience and how it works is one of the tasks of criticism.

That must mean that the verbal texture and semantics are important: indeed, they are the only road we have towards apprehending the mystery at the heart. And they can give a pretty fair line on areas of the author's concern. Helen Cooper's lucid and thought-provoking exploration across the canon of a single concept, 'hap' and its cognates, demonstrates just how deep, and how intellectually and emotionally charged, this issue was for Chaucer all through the intellectual and literary career we can know about. Much we cannot know, of course, and we can be quite certain that, as with Shakespeare, much has been lost, especially of the work of Chaucer's youth and early manhood. Alex da Costa's exploration of the implications of how the Pardoner is presented, and the uneasy relation between accident and substance, opens up a new and powerful historical/cultural perspective. William A. Quinn explores indeterminacy and ambiguity as qualities radical to 'The Man of Law's Tale', examining some of the points of fracture in the narrative where Chaucer's fictional cosmos might slide for different readers into alternative realities.

Ad Putter's elegant article shows how what some might see as a very technical exploration of prosody can genuinely illuminate not only Chaucer's meticulous command of sonic effects, but also the conceptual intricacies of Chaucer's work, and the way those effects enhance the semantic patterns and structures - and how they are read. Too many people now read poetry with tin ears, and the sophisticated music of Chaucer's verse is a far more complex and considered thing than most realize. Readers who do not hear it in their heads, or indeed who do not read it aloud, miss so much of its pleasure and wit. This article, indeed, reminds us too of what we, alas, have not: Chaucer's youthful 'enditynges of worldly vanite ... many a songe and many a leccherous lay' presuppose a musical/metrical talent, which the verse we do have, of his late twenties and after, develops and hones into something virtuoso.

Chaucer the Author had real people who were readers, and he released his poems, as he himself says (e.g. Troilus and Criseyde, V.1786ff.), into a future he knew would be different from the mental and physical world in which he lived. (Robert Henryson allows us a glimpse of one of those new worlds.) Sebastian Sobecki's article reminds us forcefully not only of the nexus of relationships, even the minutiae of place, within which 
Chaucer himself worked, but also the dynamics of the early circulation of his work. For if it be true, as suggested above, that poems 'read' the readers, how readers read - both physically and conceptually - is an important concern and one to which Chaucer himself seems to have been alert. My own article on the form and structure of The Parlement of Foulys argues for Chaucer being quite aware that the poem as it might be heard - indeed performed - and the poem read are quite different things, and that he makes that tension, contradiction even, part of the issues the poem discusses. If there be any force in this argument, it suggests that other poems, and not only of Chaucer, might also be fruitfully re-examined on these terms.

This collection of articles is an homage to a toweringly great poet, but also an acknowledgement of the intellectual excitement, challenge and pleasure on so many levels that readers individually owe to him. No two read him alike. Chaucer lived in a world where many things were unimaginably and unknowably different, and he is the child of a specific cultural episteme, the heir of its imperatives and priorities. But the mere fact of his work, his reaction to that world, changed the way it could think of itself and the language in which it could express human experience, and unfolding what we can know of how he worked and could have thought - 'the craft so longe to lerne' - can be intensely rewarding and challenging, as anyone who teaches knows, for both teacher and taught. His poems still have the capacity to change the way we, in a world of which he is one of the ancestors, can see and engage with the fundamental questions of knowledge, understanding, beauty and pleasure.

C.W.R.D. Moseley teaches in the Faculty of English at the University of Cambridge, and has been Director of Studies in English for several colleges of the university as well as Programme Director of the university's International Summer Schools in English Literature and Shakespeare. 


\section{Notes}

1. See J.C. Carlier [C.T. Watts], 'Roland Barthes's Resurrection of the Author and Redemption of Biography', Cambridge Quarterly 29, no. 4 (2000): 386-393.

2. Gerard Manley Hopkins, 'That Nature is a Heraclitean Fire and of the comfort of the Resurrection', (1888), lines 23-4.

3. Cf. A.C. Spearing, Textual Subjectivity (Oxford: Oxford University Press, 2005), 101-136.

4. Joseph Conrad, Heart of Darkness (London: Penguin, 2007 [1899]), 6. 